\title{
On Laozi's Thought of "Doing Nothing and Governing" and the Application of Thematic Teaching in Senior High School Politics Class
}

\author{
Jing Jin ${ }^{1}$, Liandong Wang ${ }^{2, *}$ \\ ${ }^{1}$ School of China Metrology University of Humanities \& Foreign Languages, Hangzhou, Zhejiang 310018, China \\ ${ }^{2}$ School of China Metrology University of Humanities \& Foreign Languages, Hangzhou, Zhejiang 310018, China \\ *Corresponding author. Email: wangliandong@foxmail.com
}

\begin{abstract} thematic teaching.

\section{INTRODUCTION}

"Doing nothing and governing" is the soul of Laozi's thought. With the official release of "General High School Ideological and Political Curriculum Standard (2017 Edition)", it can be seen that the cultivation of students' core literacy is becoming more and more important, and issue-based teaching as a new teaching method plays an important role in cultivating students' core literacy. The thought of "doing nothing and governing" fully fits the concept of issue-based teaching, however, the author finds that in many studies of issue-based teaching, few researchers discuss it from the perspective of "doing nothing and governing" thought. In view of this, this paper will use the idea of "doing nothing and governing" to explore the high school political topic teaching research, in order to promote the high school political teaching reform and development.
\end{abstract}

Laozi's thought of "doing nothing and governing"means to follow the natural law of development of things and not to act presumptuously, so as to achieve "doing nothing and governing". The idea of "doing nothing and governing" is of great significance to the realization of the fundamental task of the education of "establish moral education". Issue-based teaching is the teaching of activity-based subject courses designed around issues. It is conducive to China's continuous deepening of basic education curriculum reform and the cultivation of core literacy in ideology and political science. Based on the thought of "doing nothing and governing", this paper will analyze the internal unity between the thought of "doing nothing and governing"and the issue-based teaching, which will certainly bring benefits to the high school political

Keywords: Lao zi, doing nothing and governing, thematic teaching, high school politics

\section{THE CONNOTATION OF LAOZI'S THOUGHT OF "DOING NOTHING AND GOVERNING"}

\subsection{Let Nature Take Its Course}

Lao Zi believes that "man follows the laws of the earth, the earth follows the laws of the sky, the sky follows the laws of the Tao, and the Tao follows the laws of nature", and doing nothing and governing means following the natural trends and objective laws of development, and opposing recklessness that goes against the nature of nature and social laws. Chapter 27 of the Tao Te Ching: "Good deeds, no rut; good words, no flawed relegation; good numbers, no need to plan; good closure, no key not open; good knot, no rope covenant and can not be solved. The sage is good at saving people, so there is no abandonment of people, always good at saving things, is said to attack the bright. Therefore, good people, not good people of the teacher; not good people, good people of the capital, although to the great mystery, is the medicine is wonderful"[2], meaning that people should respect the law, all things have their own laws of operation, do not change the law, will be less detours, go along with the road to long.

\subsection{Moderation}

This is Laozi's description of the movement of the Tao. When things develop to a certain limit, they will move in the opposite direction, so we should pay attention to the state of development of things and stop them from transforming to the opposite direction in time. Therefore, we should pay attention to the state of development of things and stop them from transforming into the opposite direction in time. In this way, we must grasp a certain degree in dealing with people in the world, and we should not go too far in doing things. The Tao Te Ching Chapter 58: "Misfortune is a blessing, blessing is a curse", things can be transformed into each other under certain conditions [2]. As the Tao Te Ching Chapter 44 says: "The greatest disaster is not knowing enough, the greatest blame is not wanting to get, only know enough, can know enough 
not humiliate, know stop not dangerous, can always be long",[2] so we have to pay attention to grasp the degree of doing things.

\subsection{Doing something But not everything}

Chapter 21 of the Tao Te Ching: "In a trance, there is an image. The trance is indistinct, in which there are things. Mythic and meditative, in which there is essence. Its essence is very true, and there is faith in it."[2] Nothing is not nothing, but in nothing there is infinite vitality and a variety of possibilities, uncertainty. Nothing is the existence and development of something, while nothing is what it was before it was created. To do nothing is not to do nothing, but to do something in accordance with the law, not to act presumptuously; and in the process of doing so, to grasp the movement of things in time to reach an optimal state.

\section{PROBLEMS IN THE IMPLEMENTATION OF THEMATIC TEACHING IN HIGH SCHOOL POLITICS CLASS}

\subsection{The Choice of Topics is not Closely Related to the Content of the Subject}

High school ideology and politics is a very practical subject, and the knowledge it contains is rooted in the real social life, and the course content of the subject is constantly enriched and improved, but in the real teaching, the topics chosen by some teachers are not closely enough connected with the content of the subject to make issuebased teaching better serve the teaching of high school ideology and politics.

\subsection{Lack of Openness and Speculation in Problem Design}

The General High School Ideology and Politics Curriculum Standards (2017 Edition) states that "the socalled issues in teaching ideology and politics should include both the specific course content of the subject and present the basic ideas of value judgment; they should be open and leading, and also be able to show the important and difficult points of teaching."[1] The use of issue-based teaching in high school political teaching has put forward high requirements to the majority of ideological and political teachers, but at present some teachers are still in the traditional education stage of issue design, not fundamentally updated, the openness and discursive understanding of issue-based teaching problem design is not deep enough, affecting the teaching effect, and in the teaching process there are students do not understand the problem, students participate in issue-based teaching Some problems such as students' lack of understanding of the issues and students' lack of awareness in issue-based teaching.

\subsection{The Implementation Process does not Give Students Sufficient Space for Discussion}

Topic teaching emphasizes the exertion of students' subjectivity and fully arouses students' autonomy and enthusiasm in learning. Students' consciousness and ability to participate in topic teaching directly affect the effect of topic teaching. In practical classroom teaching, although most students are used to teaching students to listen to such a teaching method, but in the subconscious mind of students, there are still most students more inclined to explore the way of learning. It can be seen that it is not that students do not want to explore independently, but that the current teaching model does not give them opportunities and space. Teachers can not break the original teaching mode, can not improve the space for students to explore independently, is not conducive to making students really become masters of learning.

\subsection{Teaching Evaluation Emphasizes the Result over the Process}

In the teaching practice of high school ideology and politics class, most students think that teachers occasionally or never evaluate their performance in the process of activities, which has to cause teachers to pay attention to and reflect on the process of issue-based teaching implementation, teachers have to evaluate the process of student learning and authentic evaluation, but in the actual teaching process, due to the limitations of many factors, there is no more However, in the actual teaching process, due to many factors, there is no more time and space to evaluate students' process performance. At the same time, what is more crucial is that teachers do not have the right evaluation methods to match with the implementation of issue-based teaching, and even if there is evaluation, it mostly stays at the verbal level, without subdivided levels and standards, without a set of real and observable evaluation mechanism, which leads to the lack of operability of the existing activity evaluation, precisely because the evaluation mechanism is not feasible and lacks operability, which eventually leads to the classroom of issue-based teaching The feedback evaluation is formal and focuses only on the results but not the process. 


\section{THE INSPIRATION OF THE IDEA OF "DOING NOTHING AND GOVERNING" TO THE THEMATIC TEACHING OF HIGH SCHOOL POLITICS CLASS}

\author{
4.1. Choose Topics Suitable for Subject \\ Content
}

\subsubsection{Close to the actual choice of life issues}

The topic setting should be close to the students' life, so students' thinking and inquiry. Students are the main body of the teaching process. Taking the students' personal life experience and the problems that are difficult to understand and judge in life as the topic, can make students participate more actively in the discussion of the subject, can arouse students' interest in learning and participation, and have more authenticity in the creation of the situation. It is also helpful to improve the thinking patterns and functions existing in the students' life experience and form a new understanding.

\subsubsection{Pay attention to social hot spot selection issues}

In teaching, teachers can use the current social hot spots as the material for students' discussion, but many of these hot spots are useless and negative issues, so teachers should pay attention to the selection of valuable topics for students to study. According to Lao Zi: "The world's divine tools are not to be done, and not to be executed. The one who does is defeated, and the one who does is lost. The sage does not do anything, so there is no failure; no obsession, so there is no loss." Don't choose inappropriate topics just to arouse students' interest and to make them fresh.

\subsubsection{Choose the topic around the teaching focus}

Activity design should be aimed at the important and difficult points of teaching, out of the curriculum content of the core accomplishment of the subject, in the form of activity, we should adopt the activity form which can enhance the accomplishment, design the student's independent inquiry and the student's exchange and cooperation, so that students can acquire the key knowledge, necessary quality and key ability of the subject in the process. Therefore, in determining the teaching focus should be accurate, concise, do not set too many issues not related to the teaching focus.

\subsection{Go with the Flow, Combining Student Independent Thinking with Collaborative Inquiry}

\subsubsection{Create a relaxed atmosphere for cooperative inquiry}

According to Lao $\mathrm{Zi}: "$ The Tao is always without action and without inaction; if the marquis can keep it, all things will transform themselves." Instead of putting the teacher in the main position, the teacher is put in the leading position to guide students' learning. The most prominent feature of the topic-based teaching method is to transform the teacher's teaching style and the students' learning style, and give full play to the students' subjectivity. In order to fully demonstrate the guiding role of topics in teaching, teachers can use cooperative inquiry-based teaching methods to enhance group cooperation, teacher-student interaction, and strengthen the exchange of group thinking and emotions.

\subsubsection{Provide speaking time to show the results of the inquiry}

Display communication is the most attractive and dynamic part of the classroom. In their speeches, the students showed the results of the discussion in this group, rubbed the sparks of thinking in the display of the results, constantly explored in the collision of thinking, and finally checked and filled the gaps through the guidance of teachers, encouraging students to think rationally. Solve problems with scientific spirit. When speaking, the teacher should not deliberately go to the students must come to what results, students in free discussion when the spark of thought is often a wonderful part of a class.

\subsection{Teachers' Comments and Summaries}

\subsubsection{Be good at finding bright spots and evaluate students comprehensively}

The evaluation of topic teaching pays more attention to the performance of learners in the process of learning and independent exploration, problem inquiry and so on, so it pays more attention to the application of process evaluation in the evaluation. Although sometimes the results of learning are not satisfactory, the enthusiasm and flash of students in the process of learning need teachers to find out, teachers should find out the advantages of students in time, and find out to encourage students, so that students have confidence, Interested in continuing to study, if the results of the study will inevitably hit the enthusiasm of students. 


\subsubsection{Grasp the students' learning trends and states}

Lao Zi said, "Disaster, good fortune, evil," things under certain conditions will transform each other. Teachers should pay attention to the students who are performing well, and teachers should also pay attention to the students who are not performing well. The teacher should pay attention to the students who are usually attentive to the lesson or struggle to understand the content of the lesson, so that they can regain their enthusiasm for learning, teachers should encourage these students.

\subsubsection{Pay attention to the development level of discipline core literacy, and promote the overall improvement of students' literacy}

The Outline of Basic Education Reform (Trial Implementation) states that it is necessary to "change the curriculum evaluation with too much emphasis on screening and selection, and give play to evaluation to promote development. Teachers improve and improve the function of teaching practice and establish a curriculum evaluation system to promote the development of students' function. We should pay more attention to the evaluation of students' innovative consciousness and habit cultivation." Therefore, the topic teaching evaluation should not only pay attention to the acquisition of students' knowledge, but also pay attention to the development of students' ability and the cultivation of emotional attitude and values, so as to promote the all-round development of students.

\section{CONCLUSION}

In recent years, new educational concepts and teaching modes have emerged, and issue-based teaching, as a new type of teaching method, is an impact and challenge to traditional teaching. At the same time, it is not only limited to the transmission of knowledge, but also focuses on the collision of ideas and the exchange of thoughts. This paper starts from Laozi's idea of "doing nothing and governing", explains the connotation of "doing nothing and governing", and analyzes the inner unity between "doing nothing and governing" and issue-based teaching. We should follow the law of students' development and make good use of Laozi's idea of "doing nothing and governing" in order to promote the continuous improvement of issue-based teaching in high school politics.

\section{REFERENCES}

[1] Ministry of Education of the People's Republic of China, General Senior High School Ideological and Political Curriculum Standard :2017 Edition, Peoples Education Press, Beijing, China, 2018, pp. 41.(In Chinese)

[2] Chen Gu Ying, Annotation and Evaluation of Lao Zi, China Publishing House, Beijing, China, 1984, pp. 174203. (In Chinese)

[3] Huang Yijing; Li Xiaodong, "Innovation is the first driving force for development" instructional design, Teaching of Ideological and Political Courses, 2019(06), pp. 66-70. (In Chinese)

[4] Li Jin; Jie Cheng, A New Classroom Pattern under the New Curriculum Standard for Topic-based Teaching, Middle School Political Teaching Reference, 2018(34), pp. 39-40. (In Chinese)

[5] Hu Jing, Laozi's thought of "governing by doing nothing" and its contemporary value, Journal of Luohe Vocational and Technical College, 2019, 18(06), pp. 64-68. (In Chinese)

[6] Xu Daoping; Zhang Zongyuan, The Thought of Lao Tzu's "Doing Nothing" and the Study of College Flip Classroom Teaching, Comparative Study on Cultural Innovation, 2019, 3(25), pp. 33-34 58. (In Chinese)

[7] Shi Wei, Revelation on the Guiding Function of Laozi's "inaction" in Moral Education of College Students, Northern Lights, 2019(04), pp. 145-146. (In Chinese)

[8] Wei Wei, Analysis of Laozi's Educational Thought, Journal of Heihe University, 2018, 9(09), pp. 186-188. (In Chinese) 